\title{
PENGARUH KEPEMIMPINAN TRANSFORMASIONAL DAN TRANSAKSIONAL TERHADAP BUDAYA ORGANISASI, MOTIVASI KERJA, KOMITMEN OGANISASIONAL DAN KINERJA KARYAWAN
}

\author{
Ida Siswatiningsih, Kusdi Raharjo, Arik Prasetya \\ Universitas Brawijaya Malang \\ Email : idaprabowo@gmail.com
}

\begin{abstract}
The purposes of this study are: to examine the influence of transformational leadership and Transactional leadership towards organizational culture, motivation, organizational commitment, and employee performance. Place of research carried out in Muhammadiyah hospital of Ahmad Dahlan Kediri, consists of 353 staff. The study sample derived from questionnaire have distributed include 130 respondents covering 81 people (62\%) health workers and 49 people (38\%) non health personnel / administrative personnel. Statistical analysis technique by Structural Equation Model (SEM) and different test. The hypothesis testing results show that: (1) Transformational leadership has a positive and significant impact towards organizational culture and organizational commitment. (2) Transactional leadership has a positive and significant impact towards organizational culture and employee performance);(3) organizational culture has a positive and significant impact towards motivation; (4) Motivation has a positive and significant effect towards organizational commitment; (5) Organizational commitment positively and significantly influence employee performance; (6) Transformational leadership has a positive but not significant effect towards motivation and employee performance;(7) Transactional leadership has a positive but not significant effect towards motivation and organizational commitment
\end{abstract}

Keywords: Employee Performance, Motivation, Organizational Commitment, Organizational Culture, Transformational Leadership, Transactional Leadership

\begin{abstract}
Abstrak : Tujuan penelitian ini adalah untuk menguji pengaruh kepemimpinan transformasional dan transaksional terhadap budaya organisasi, motivasi kerja, komitmen organisasional,dan kinerja karyawan. Tempat penelitian dilaksanakan di Rumah sakit umum Muhammadiyah Ahmad Dahlan Kediri yang memiliki pegawai sebanyak 353 orang. Sampel ditetapkan berdasarkan hasil kuesioner yang masuk sebanyak 130 responden yang meliputi 81 orang (62\%) tenaga kesehatan dan 49 orang (38\%) tenaga non kesehatan / tenaga administrasi. Teknik analisis statistik Structural Equation Model (SEM) dan uji beda. Hasil pengujian hipotesis menunjukkan bahwa (1) Kepemimpinan transformasional berpengaruh positif dan signifikan terhadap budaya organisasi dan komitmen organisasional;(2) Kepemimpinan transaksional berpengaruh positif dan signifikan terhadap budaya organisasi dan kinerja karyawan;(3) Budaya organisasi berpengaruh positif dan signifikan terhadap motivasi kerja;(4) Motivasi kerja berpengaruh positif dan signifikan terhadap komitmen organisasional;(5) Komitmen organisasional berpengaruh positif dan signifikan terhadap kinerja karyawan; (6) Kepemimpinan transformasional berpengaruh positif dan tidak signifikan terhadap motivasi kerja dan kinerja karyawan;(7) Kepemimpinan transaksional berpengaruh positif dan tidak signifikan terhadap motivasi kerja dan komitmen organisasional.
\end{abstract}

Kata Kunci: Budaya Organisasi, Kepemimpinan Transformsional, Kepemimpinan Transaksional, , Komitmen Organisasional dan Kinerja Karyawan, Motivasi Kerja 


\section{PENDAHULUAN}

Bass et al.(2003), menjelaskan faktor penting yang menentukan kinerja karyawan dan kemampuan organisasi beradaptasi dengan perubahan lingkungan adalah kepemimpinan (leadership). Pemimpin yang memiliki gaya kepemimpinan transaksional dan transformasional ini lebih mampu untuk memimpin dengan menggunakan kelebihan dan memanfaatkan masing-masing gaya tersebut pada waktu dan tempatnya (Yukl, 1998). Kepemimpinan transaksional dan transformasional dapat dipilah secara tegas dan keduanya merupakan gaya kepemimpinan yang saling bertentangan namun dapat ditemui di dalam seorang pemimpin.

Keberhasilan para pemimpin menanggapi perubahan yang terjadi memerlukan gaya kepemimpinan yang sesuai dengan tuntutan perubahan tersebut. Dalam hal ini, faktor budaya organisasi (culture organization) menjadi penting artinya bagi seorang pemimpin

Lebih lanjut Bass dan Avalio (1993) menyatakan bahwa kepemimpinan transformasional akan menghasilkan budaya transformasional. Teori ini didukung oleh penelitian yang dilakukan oleh Salain ( 2013 ) yang menemukan bahwa kepemimpinan transformasional berpengaruh positif terhadap budaya organisasi. Penelitian yang dilakukan El-Nahas,dkk ( 2012 ) : "The impact of leadership behaviour and organisational culture on job Satisfaction and its relationship among organisational commitment and turnover intentions: a case study on an Egyptian company " menghasilkan bahwa kepemimpinan transformasional tidak ada hubungan yang positif dengan budaya organisasi.

Organisasi dengan pemimpin transaksional akan menciptakan model budaya transaksional yang berkonsentrasi pada hubungan kontrak secara eksplisit dan implisit (Yukl, 1989, 1994, 2006). Penelitian Acar (2012) menunjukkan bahwa kepemimpinan transaksional berpengaruh positif pada budaya organisasi.

Budaya organisasi dapat membantu kinerja pegawai, karena menciptakan suatu tingkat motivasi yang besar bagi karyawan untuk memberikan kemampuan terbaiknya dalam memanfaatkan kesempatan yang diberikan oleh organisasi yang ditempatinya. Nilai-nilai yang dianut bersama membuat karyawan merasa nyaman bekerja dan termotivasi untuk meningkatkan kinerjanya. Budaya organisasi harus dirangsang untuk dapat memotivasi karyawan guna mencapai tujuan organisasi (Sempane dkk, 2002). Hasil penelitian Sokro ( 2012 ) dengan menggunakan metode korelasi Pearson dan Spearman, ditemukan suatu korelasi positif antara variabel budaya organisasi dan motivasi kerja. Penelitian tersebut mengungkapkan bahwa budaya organisasi memiliki dampak langsung terhadap motivasi kerja dan secara tidak langsung juga berdampak terhadap kinerja organisasi.

Banyak upaya yang telah dilakukan oleh manajemen agar karyawan memiliki motivasi, komitmen dan kompetensi terhadap organisasi. Sehingga memberikan dampak positif terhadap peningkatan kinerja. Flecther dan Williams (1996) menyatakan bahwa komitmen organisasional karyawan untuk terus bekerja menjadi bagian dari suatu organisasi akan meningkat apabila didukung adanya motivasi yang tinggi dari karyawan yang terkait dengan pekerjaannya. Burton et al (2002) yang menyatakan bahwa motivasi kerja karyawan berpengaruh signifikan positif terhadap komitmen organisasional yang diukur melalui tiga dimensi dari komitmen, yaitu affective commitment, normative commitment, dan continuance commitment.

Penelitian yang dilakukan Puspasari (2012) membuktikan hasil analisis regresi diketahui bahwa motivasi kerja dan budaya organisasi berpengaruh secara signifikan terhadap komitmen organisasional, motivasi dan budaya organisasi berpengaruh secara signifikan terhadap kinerja pegawai. Begitu juga penelitian yang dilakukan Tania dkk(2013) dalam jurnalnya yang berjudul Pengaruh Motivasi Kerja dan Kepuasan Kerja Terhadap Komitmen Organisasional pada PT Dai Knife Surabaya yang menghasilkan bahwa motivasi kerja berpengaruh secara signifikan terhadap komitmen organisasional.

Keberhasilan suatu organisasi sangat erat kaitannya dengan kualitas kinerja para anggotanya, sehingga organisasi dituntut untuk selalu mengembangkan dan meningkatkan kinerja dari para anggotanya. Armstrong dan Baron (1998) menjelaskan bahwa kinerja adalah tentang melakukan pekerjaan dan hasil yang dicapai dari pekerjaan tersebut. Menurut Dessler (1999) menunjukkan bahwa pegawai yang memiliki komitmen organisasional tinggi 
memiliki nilai absensi rendah dan memiliki masa bekerja yang lebih lama dan cenderung untuk bekerja lebih keras serta menunjukkan prestasi yang lebih baik. Hal ini didukung oleh penelitian yang dilakukan oleh Widya ( 2012 ) dalam jurnalnya yang berjudul "Pengaruh Motivasi dan Budaya Organisasi Terhadap Komitmen Organisasional dan Kinerja”. Hasil penelitian dengan analisis regresi diketahui bahwa motivasi dan budaya organisasi berpengaruh secara signifikan terhadap komitmen organisasional, motivasi dan budaya organisasi berpengaruh secara signifikan terhadap kinerja pegawai.

Penelitian ini mengabil sampel pada pegawai Rumah Sakit Muhammadiyah Ahmad Dahlan Kediri. Alasan dipilihnya rumah sakit Muhammadiyah Ahmad Dahlan Kediri dengan pertimbangan bahwa produk yang ditawarkan berupa jasa pelayanan. Artinya sebagai organisasi swasta, kebijakan awal terkait dengan kepemimpinan dan budaya organisasi hingga menunjang kinerja karyawan dalam organisasi pelayanan turut menentukan arah dan tujuan organisasi ke depannya yang mendudukan peran sumber daya manusia sebagai faktor yang sangat signifikan.

Berdasarkan uraian tersebut dan adanya temuan di lapangan pada saat pra penelitian, maka penting bagi peneliti untuk meneliti pada rumah sakit Muhammadiyah Ahmad Dahlan Kediri

\section{TINJAUAN PUSTAKA}

\section{Kepemimpinan Transformasional}

Bass (1985) mendefinisikan kepemimpinan transformasional didasarkan pada pengaruh dan hubungan pemimpin dengan pengikut atau bawahan. Para pengikut merasa percaya, mengagumi, loyal dan menghormati pemimpin, serta memiliki komitmen dan motivasi yang tinggi untuk berprestasi dan berkinerja yang lebih tinggi. Konsep kepemimpinan transformasional mengintegrasikan ide-ide yang dikembangkan dalam pendekatan watak, gaya dan kontingensi.

Bass dan Avolio (1994) menggambarkan kepemimpinan transformasional dengan membagi kedalam empat faktor, yaitu :

1. Karismatik (dealized influence)

2. Inspirasional (inspirational motivation)

3. Stimulasi intelektual (intellectual stimulation)

4. Perhatian secara individual (individualized consideration)

\section{Kepemimpinan Transaksional}

Menurut Bass (1985) pemimpin transaksional memotivasi pengikutnya dengan cara menukar imbalan untuk pekerjaan atau tugas yang telah dilaksanakan misalnya dengan penghargaan, menaikkan upah terhadap pengikutnya yang melakukan kinerja yang tinggi. Tetapi sebaliknya akan memberikan penalti (punishment) terhadap pengikutnya yang mempunyai kinerja yang rendah atau berada di bawah target.

Menurut Burns (1978) mengemukakan bahwa kepemimpinan transaksional memiliki empat karakteristik, yaitu:

1. Contigent Reward

2. Management by Exception (Active)

3. Management by exception (Passive)

4. Laissez-faire

\section{Budaya Organisasi}

Schein ( 1996 ) mendefinisikan budaya organisasi sebagai wujud anggapan yang dimiliki, diterima secara implisit oleh kelompok dan menentukan bagaimana kelompok tersebut rasakan, pikirkan, dan bereaksi terhadap lingkungannya yang beraneka ragam.

Robbins (2006), dalam penelitian yang dilakukannya memberikan tujuh karakteristik yang dapat menangkap esensi budaya organisasi. Ketujuh karakteristik tersebut adalah (1)Inovasi dan keberanian mengambil risiko, (2)Perhatian terhadap hal-hal yang rinci, (3)Orientasi hasil,(4) Orientasi orang,(5)Orientasi tim, (6)Keagresifan, (7) Stabilitas.

\section{Motivasi Kerja}

Menurut Robbins (2006) motivasi sebagai kesediaan karyawan untuk mengeluarkan tingkat upaya yang tinggi untuk tujuan organisasi, yang dikondisikan oleh kemampuan upaya itu untuk memenuhi beberapa kebutuhan individual. Sedangkan menurut Gibson et al. (1996) motivasi merupakan kekuatan yang mendorong seseorang karyawan yang menimbulkan/ mengarahkan perilaku, atau suatu proses dimana perilaku diberikan energi dan diarahkan. David McClelland dikenal menjelaskan tiga jenis motivasi, yaitu :

1. Kebutuhan akan berprestasi / Need of achievement (nAch)

2. Kebutuhan akan kekuasaan / Need of power (nPow) 
3. Kebutuhan akan berafiliasi/ Need of affiliatin (nAff).

Dalam teorinya McClelland mengemukakan bahwa individu mempunyai cadangan energi potensial, bagaimana energi ini dilepaskan dan dikembangkan tergantung pada kekuatan atau dorongan motivasi individu dan situasi serta peluang yang tersedia.

\section{Komitmen Organisasional}

Komitmen adalah suatu kondisi psikologis yang menggambarkan hubungan karyawan dengan organisasi mereka dan memiliki implikasi terhadap keputusan untuk tetap menjadi anggota organisasi. Luthans (2005) menyatakan bahwa komitmen organisasi adalah sikap yang merefleksikan loyalitas karyawan pada organisasi dan proses berkelanjutan dimana anggota organisasi mengekspresikan perhatiannya terhadap organisasi dan keberhasilan serta kemajuan yang berkelanjutan.

Salah satu model Komitmen Organisasi Multidimensional milik Meyer dan Allen (1991) menjadi populer dan memperoleh dukungan empiris dari berbagai kultur yang berbeda; Allen \& Meyer, 1996; Model TigaKomponen yang tediri dari Komitmen Afektif (KA), Komitmen Kontinyu (KK), dan Komitmen Normatif (KN). KA mengacu pada ikatan emosional, identifikasi, dan keterlibatan dalam organisasi. KK mengacu pada suatu ikatan berdasarkan akumulasi biaya, seperti pensiun, kompensasi keahlian, relokasi, dan investasi diri yang covary dengan keanggotaan organisasi. Terakhir, KN mengacu pada perasaan memiliki kewajiban untuk terus berada di dalam organisasi.

\section{Kinerja Karyawan}

Kinerja karyawan merupakan prestasi kerja, yakni perbandingan antara hasil kerja dengan standar kerja yang ditetapkan (Dessler, 1997). Definisi kinerja karyawan menurut Mangkunegara (2001) adalah hasil kerja secara kualitas dan kuantitas yang dapat dicapai oleh seorang pegawai dalam melaksanakan tugas sesuai dengan tanggung jawab yang diberikan kepadanya. Sedangkan Simamora (1995) mendifinisikan kinerja karyawan sebagai suatu tingkatan dimana para karyawan mencapai persyaratan-persyaratan pekerjaan

Ada enam kriteria primer yang digunakan untuk mengukur kinerja karyawan menurut Bernardin dan Russel (dalam Martoyo, 2000), yaitu :

1. Quality; merupakan tingkat sejauh mana proses atau hasil pelaksanaan kegiatan mendekati kesempurnaan atau mendekati tujuan yang diharapkan.

2. Quantity; merupakan jumlah yang dihasilkan.

3. Timeliness ; adalah tingkat sejauh mana suatu kegiatan diselesaikan pada waktu yang dikehendaki

4. Cost-effectiveness; yaitu tingkat sejauh mana penggunaan daya organisasi

5. Need for supervision; merupakan tingkat sejauh mana seorang pekerja daat melaksanakan suatu fungsi pekerjaan tanpa memerlukan pengawasan seorang supervisor

6. Interpersonal impact, merupakan tingkat sejauh mana karyawan/pegawai memelihara harga diri, nama baik dan kerja sama di antara rekan kerja dan bawahan.

\section{Pengaruh Kepemimpinan Transformasional Terhadap Budaya Organisasi}

Bass dan Avalio (1993) menyatakan bahwa kepemimpinan transformasional akan menghasilkan budaya transformasional. Budaya transformasional merupakan budaya yang mendorong dan mendukung inovasi dan diskusi terbuka mengenai isu-isu dan ide-ide sehingga menjadikan tantangan sebagai kesempatan. Didukung oleh penelitian yang dilakukan oleh Salain, dkk ( 2013 ) yang menemukan bahwa kepemimpinan transformasional berpengaruh positif terhadap budaya organisasi.

\section{Pengaruh Kepemimpinan Transaksional Terhadap Budaya Organisasi \\ Organisasi dengan pemimpin}

transaksional akan menciptakan model budaya transaksional yang berkonsentrasi pada hubungan kontrak secara eksplisit dan implisit (Yukl, 1989, 1994, 2006), demikian juga penelitian yang dilakukan Acar (2012) menujukkan bahwa kepemimpinan transaksional berpengaruh positif pada budaya organisasi.

Pengaruh Kepemimpinan Transformasional Terhadap Motivasi Kerja

Motivasi kerja seorang pegawai dipengaruhi oleh kepemimpinan transformasional dimana gaya kepemimpinan 
seperti ini dapat meningkatkan kinerja dan motivasi (Bass, 1985). Penelitian yang dilakukan Solechah dkk ( 2011) menyatakan bahwa gaya kepemimpinan transformasional berpengaruh signifikan dan positif secara langsung terhadap motivasi kerja.

\section{Pengaruh Kepemimpinan Transaksional Terhadap Motivasi Kerja}

Kepemimpinan transaksional adalah pemimpin yang membimbing atau memotivasi bawahan mereka ke arah tujuan yang telah ditetapkan dengan memperjelas peran dan tuntutan tugas, Robbins (2011). Hal ini juga didukung pada penelitian yang dilakukan oleh Chaudhry ( 2012 ) yang dalam penelitiannya diketahui adanya pengaruh kepemimpinan transaksional terhadap motivasi kerja

\section{Pengaruh Kepemimpinan Transformasional Terhadap Komitmen Organisasional}

Kepemimpinan transformasional mempunyai pengaruh terhadap komitmen organisasional, terutama dalam memobilisasi komitmen dalam suatu organisasi yang mengalami perubahan (Noel M. Tichy \& David 0. Urlich, 1984).Penelitian yang dilakukan Griffith (2013 ) yang memperkirakan adanya pengaruh yang positif antara gaya kepemimpinan transformasional dengan komitmen organisasional dan hasil yang didapat menyatakan bahwa adanya efek positif antara kepemimpinan transformasional dan komitmen organisasional.

\section{Pengaruh Kepemimpinan Transaksional Terhadap Komitmen Organisasional}

Menurut teori, hubungan antara pemimpin transaksional dengan bawahannya menganut sistem pertukaran ekonomi berdasarkan transaksi. Pemimpin yang transaksional dianggap 'instrumental' dan seringkali fokus pada hubungan transaksi dengan bawahannya (Bass \& Avolio, 1993). Jadi, hal tersebut dapat dikatakan efektif dan memuaskan harapan baik dari pihak atasan maupun bawahan dalam jangka pendek. Pemimpin yang menggunakan peranan dan persyaratan tugas yang jelas sebagai kriteria dan juga memberikan imbalan kontigensi yang sasuai dengan harapan karyawan dapat mempengaruhi tingkat komitmen karyawan terhadap organisasi mereka. Yukl (1994) mengungkapkan bahwa pemimpin yang efektif mempengaruhi para pengikutnya untuk mempunyai optimisme yang lebih besar, rasa percaya diri, serta komitmen kepada tujuan dan misi organisasi.

Sesuai dengan penelitian yang dilakukan oleh Prasteyo (2008) yang menyatakan bahwa Kepemimipinan transaksional memiliki keterkaitan positif pada komitmen organisasional.

\section{Pengaruh Budaya Organisasi Terhadap Motivasi Kerja}

Kaitan antara motivasi dengan kultur dapat terlihat melalui lima sumber motivasi yang dikemukakan oleh Kanter (1989). Kanter menjelaskan bahwa karyawan dapat termotivasi melalui misi (menginspirasi karyawan untuk meyakinkan bahwa hasil kerja mereka sangat berarti), kontrol agenda (memberi peluang kepada karyawan untuk mengontrol karir mereka), menciptakan nilai bersama (memberikan reward bagi karyawan yang sukses), pembelajaran (memberi kesempatan karyawan untuk belajar) dan reputasi (memberi peluang bagi karyawan untuk memperoleh reputasi mereka). Kelima sumber motivasi tersebut berkaitan dengan pendapat Denison (1990) dan Truskie (1999) dimana ada tiga sumber motivasi yang fokus pada bidang yang sama. Menurut Simamora, (1995:327) dalam suatu organisasi modern, peran lingkungan dan adanya motivasi adalah melakukan sejumlah fungsi, antara lain memperkuat organisasi beserta perangkat kerjanya, menerapkan tapal batas artinya menciptakan perbedaan yang jelas antara suatu organisasi dengan organisasi lainnya, memberi standar yang tepat untuk apa yang harus dikatakan dan apa yang dilakukan oleh para pegawai, sebagai mekanisme pembuat makna dan kendali yang memadu dan membentuk sikap serta perilaku dan motivasi pegawai. Hal ini di dukung oleh penelitian Sokro ( 2012 ) yang meneliti bahwa kultur organisasi memiliki dampak langsung terhadap motivasi kerja karyawan dan secara tidak langsung juga berdampak terhadap kinerja organisasi. Semakin tinggi kultur organisasi, maka semakin tinggi pula tingkat motivasi karyawannya. Hasil observasi menunjukkan bahwa jika suatu organisasi dapat mengembangkan kultur yang kuat tentang pemberian reward dan pengakuan atas usaha para karyawannya, maka hal ini dapat meningkatkan motivasi sehingga kinerja mereka juga akan meningkat. 


\section{Pengaruh Motivasi Kerja Terhadap Komitmen Organisasional}

Lyons et al (1993) dan Flecther dan Williams (1996) menyatakan bahwa komitmen organisasional karyawan untuk terus bekerja menjadi bagian dari suatu organisasi akan meningkat apabila didukung adanya motivasi yang tinggi dari karyawan yang terkait dengan pekerjaannya.Kerja keras yang dilakukan dengan adanya dorongan atau motivasi akan menghasilkan kepuasan tersendiri bagi karyawan dalam melakukan pekerjaannya. Kepuasan kerja dan motivasi kerja sangat berkaitan langsung dengan komitmen organisasional (Mathiew dan Jones 1991). Penelitian yang dilakukan Puspasari ( 2012 ) membuktikan bahwa motivasi dan budaya organisasi berpengaruh secara signifikan terhadap komitmen organisasional.Begitu juga dengan penelitian yang dilakukan oleh Tania dkk (2013) dalam jurnalnya yang berjudul Pengaruh motivasi kerja dan kepusasan kerja terhadap komitmen organisasional pada karyawan PT Dai Knife Surabaya yang menghasilkan bahwa motivasi kerja berpengaruh secara signifikan terhadap komitmen organisasional.

\section{Pengaruh Komitmen Organisasional Terhadap Kinerja Karyawan \\ Meyer dan Allen (1990) dalam} studinya menemukan hubungan yang positif antara komitmen organisasi afektif dan kinerja. Penelitian yang dilakukan Widyaningrum ( 2012 ) mendukung pendapat dari Meyer dan Allen dimana dampak dari komitmen organisasi terhadap Kinerja terbukti dapat diterima.

\section{Pengaruh Kepemimpinan Transformasional Terhadap Kinerja Karyawan}

Luthans (2006) menyatakan bahwa kepemimpinan transformasional membawa keadaan menuju kinerja karyawan yang tinggi pada organisasi yang menghadapi tuntutan pembaharuan dan perubahan. Hasil penelitian tersebut didukung oleh penelitian terdahulu yang dilakukan oleh: Bass dan Avolio (1993) yang menunjukkan pengaruh positif kepemimpinan terhadap kinerja karyawan. Penelitian yang dilakukan Solechah, dkk ( 2011 ) menerangkan bahwa kepemimpinan transformasional berpengaruh signifikan terhadap variabel kinerja. Rasyid (2013) dalam penelitiannya juga menerangkan bahwa terdapat hubungan yang positif dan signifikan pengaruh kepemimpinan transformasional terhadap kinerja karyawan.

\section{Pengaruh Kepemimpinan Transaksional Terhadap Kinerja Karyawan}

(Bass, 1998) mendefinisikan bahwa kepemimpinan transaksional terjadi ketika insentif dan kontrol oleh pemimpin tergantung pada kecukupan kinerja pengikutnya. Penelitian yang dilakukan oleh (Burke, Stagl, Klein, Goodwin, \& Halpin, 2006) tentang perilaku kepemimpinan dan hasil kinerja tim menunjukkan bahwa perilaku kepemimpinan transaksional secara signifikan berhubungan dengan kinerja tim. Hubungan antara kepemimpinan transaksional dengan kinerja juga dikaji oleh (Rowold \& Schlotz, 2009). Dalam kajian mereka, mereka menjelaskan bahwa kepemimpinan transaksional merupakan perdagangan transaksi yang eksplisit, hasil dari transaksi ini, imbalan yang diberikan oleh pemimpin dapat menguatkan kinerja para pengikutnya. . Menurut (Avolio. Bass, \& Jung, 1999) mengemukakan bahwa dukungan yang cukup dapat membuat kepemimpinan transaksional lebih efektif, penggunaan imbalan kontigensi yang tepat menjadi umpan balik untuk membangun harapan bersama para pengikutnya dalam hal kinerja mereka. Pemimpin memberikan imbalan atau penghargaan tertentu (misalnya, bonus) kepada bawahan jika bawahan mampu memenuhi harapan pemimpin yaitu misalnya, kinerja karyawan tinggi Maulizar et,al (2012). Sementara penelitian yang dilakukan Hartanto (2014) menghasilkan bahwa kepemimpinan transaksional mempunyai pengaruh yang signifikan terhadap kinerja karyawan.

\section{KERANGKA KONSEP DAN HIPOTESIS PENELITIAN}

Berdasarkan hasil penelitian terdahulu dan teori yang telah dikemukakan, diperoleh gambaran untuk penyusunan kerangka konsep penelitian sebagai berikut:

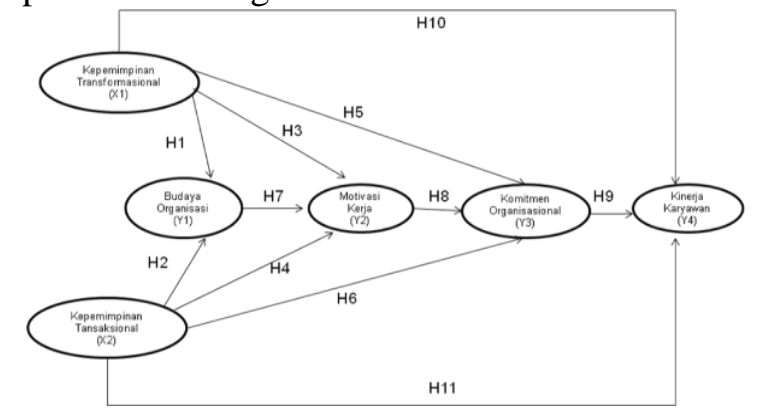


Berdasarkan model hipotesis penelitian yang telah dibuat, maka dirumuskan hipotesis penelitian sebagai berikut :

1. Hipotesis 1 : Kepemimpinan transformasional berpengaruh positif dan signifikan terhadap budaya organisasi

2. Hipotesis $2:$ Kepemimpinan transaksional berpengaruh positif dan signifikan terhadap budaya organisasi

3. Hipotesis 3 : Kepemimpinan transformasional berpengaruh positif dan signifikan terhadap motivasi kerja

4. Hipotesis $4:$ Kepemimpinan transaksional berpengaruh positif dan signifikan terhadap motivasi kerja

5. Hipotesis 5: Kepemimpinan transformasional berpengaruh positif dan signifikan terhadap komitmen organisasional

6. Hipotesis $6:$ Kepemimpinan transaksional berpengaruh positif dan signifikan terhadap komitmen organisasional

7. Hipotesis 7 : Budaya organisasi berpengaruh positif dan signifikan terhadap motivasi kerja

8. Hipotesis 8 : Motivasi kerja berpengaruh positif dan signifikan terhadap komitmen orgnisasional

9. Hipotesis 9 : Komitmen organisasional berpengaruh positif dan signifikan terhadap kinerja karyawan

10. Hipotesis 10 : Kepemimpinan transformasional berpengaruh positif dan signifikan terhadap kinerja karyawan

11. Hipotesis 11 : Kepemimpinan transaksional berpengaruh positif dan signifikan terhadap kinerja karyawan

\section{DESAIN PENELITIAN}

Data pada penelitian ini diperoleh dengan menyebarkan kuesioner kepada responden yang terdiri atas tenaga kesehatan dan tenaga non kesehatan / administrasi pada rumah sakit Muhammadiyah Ahmad Dahlan Kediri.Penyebaran kuesioner sebanyak 225 lembar dan kuesioner kembali sebanyak 135 kuesioner atau sekitar 60\%.Kuesioner tidak kembali sebesar $40 \%$ dan rusak $2 \%$.Sehingga kuesioner yang kembali dan bisa diolah sebesar 58\% setara dengan 130 kuesioner.

Teknik analisis statistik dalam penelitian ini menggunakan Structural Equation Model (SEM). Alasan dipilihnya SEM sebagai analisa statistik antara lain bahwa dalam fenomena manajemen (Bisnis) sebuah variabel tergantung dapat dipengaruhi oleh beberapa variabel bebas, demikian juga beberapa variabel bebas mampu mempengaruhi beberapa variabel tergantung.

\section{HASIL DAN PEMBAHASAN}

Hipotesis pertama (H1) yang menyatakan Kepemimpinan transformasional berpengaruh positif dan signifikan terhadap budaya organisasi dapat diterima. Hal ini dibuktikan hasil analisis yang menunjukkan terdapat pengaruh positif dan signifikan dengan koefisien $(0,341)$ dan p-value $(0,000)$, yang artinya bahwa kepemimpinan transformasional yang meningkat akan secara signifikan meningkatkan budaya organisasi. Pengujian hipotesis yang dilakukan membuktikan bahwa ada pengaruh yang searah antara Kepemimpinan Transformasional Terhadap Budaya Organisasi. Hal ini sesuai dengan pendapat Bass dan Avalio (1993), Sarros et al (2005) dan penelitian yang dilakukan oleh Salain, dkk ( 2013 )

Hipotesis kedua (H2) yang menyatakan Kepemimpinan transaksional berpengaruh positif dan signifikan terhadap budaya organisasi dapat diterima. Hasil analisis menunjukkan terdapat pengaruh positif dan signifikan dengan koefisien $(0,811)$ dan p-value $(0,000)$, yang artinya bahwa kepemimpinan transaksional yang meningkat akan secara signifikan meningkatkan budaya organisasi. Pada pengujian pengaruh langsung dihasilkan Budaya Organisasi (Y1) secara signifikan dipengaruhi oleh Kepemimpinan Transformasional (X1) dengan koefisien $(0,341)$ dan C.R $(4,352)$ dan Kepemimpinan Transaksional (X2) dengan koefisien $(0,811)$ dan C.R (6,874). Hal ini menunjukkan bahwa pengaruh secara langsung terhadap Budaya Organisasi (Y1) lebih tinggi dipengaruhi oleh Kepemimpinan Transaksional (X2). Hal ini mendukung pendapat dari Yukl, (1989, 1994, 2006) dan penelitian yang dilakukan oleh Schein, (1997), Acar (2012)

3.Pengaruh Kepemimpinan Transformasional Terhadap Motivasi Kerja

Hipotesis ketiga (H3) yang menyatakan Kepemimpinan transformasional berpengaruh positif dan signifikan terhadap motivasi kerja pada rumah sakit Muhammadiyah Ahmad Dahlan Kediri, tidak terbukti. Hal ini ditunjukkan pada hasil analisis terdapat pengaruh positif dan tidak signifikan $(\beta=-0.153, p=0.263)$, yang artinya bahwa 
kepemimpinan transformasional yang meningkat tidak akan meningkatkan motivasi kerja. Hal ini didasarkan pada hasil uji statistik pada variabel kepemimpinan transformasional nilai paling rendah pada indikator inspirasional (inspirational motivation) dimana butir pertanyaan item nomor 4 mengenai tindakan yang dilakukan pimpinan sesuai harapan merupakan butir pertanyaan yang diberi penilaian paling rendah oleh responden dengan skor 3,51. Artinya kepemimpinan yang ada di rumah sakit Muhammadiyah Ahmad Dahlan Kediri tindakannya belum sesuai dengan harapan para pegawainya. Karyawan yang merasa senang dengan pemimpinya, maka akan memicu motivasi kerja yang tinggi, Yukl (2006). Penelitian ini tidak mendukung pendapat Robbins (2011), Bass (1985) dan tidak mendukung penelitian yang dilakukan oleh Chaudhry ( 2012 ) dan penelitian Tucunan (2014)

Hipotesis keempat (H4) yang menyatakan Kepemimpinan transaksional berpengaruh positif dan signifikan terhadap motivasi kerja pada rumah sakit Muhammadiyah Ahmad Dahlan Kediri, tidak terbukti. Hal ini ditunjukkan pada hasil analisis yang menunjukkan bahwa terdapat pengaruh positif dan tidak signifikan $(\beta=0.346, p=$ 0.263), yang artinya bahwa kepemimpinan transaksional yang meningkat tidak akan meningkatkan motivasi kerja. Faktor yang diduga menjadi penyebab tidak signifikannya kepemimpinan transaksional terhadap motivasi kerja adalah bahwa pegawai pada rumah sakit Muhammadiyah Ahmad Dahlan termotivasi kerja tidak didasarkan pada pertukaran ekonomis yang biasanya dilakukan oleh kepemimpinan transaksional. Pegawai melakukan tugasnya karena adanya pengakuan dari lingkunan sekitar atas profesinya dan hal itu menimbulkan motivasi kerja yang tinggi. Faktor lain yang membuat kepemimpinan transaksional berpengaruh tidak signifikan terhadap motivasi kerja yaitu pada analisa uji beda yang mendapatkan hasil adanya perbedaan pada tingkat pendidikan dan bidang tenaga kerja. Pada uji beda pada tingkat pendidikan, diketahui bahwa terdapat perbedaan rata-rata skor Kepemimpinan Transaksional $(\mathrm{X} 2)$ di mana p-value $(0,025)$ lebih kecil dari alpha $(0,050)$. Selain itu, dapat diketahui rata-rata skor Kepemimpinan Transaksional (X2) tertinggi pada responden pendidikan SLTA dan rata-rata skor
Kepemimpinan Transaksional (X2) terendah pada responden pendidikan D3. Selanjutnya dari karakteristik bidang kerja, diketahui bahwa terdapat perbedaan rata-rata skor Kepemimpinan Transaksional (X2) di mana pvalue $(0,001)$ lebih kecil dari alpha $(0,050)$. Selain itu, dapat diketahui rata-rata skor Kepemimpinan Transaksional (X2) tertinggi pada responden tenaga non kesehatan dan ratarata skor Kepemimpinan Transaksional (X2) terendah pada responden tenaga kesehatan. Penelitian ini tidak mendukung pendapat dari Robbins (2011), Bass (1985), Thomas (2002) dan tidak menduung penelitian yang dilakukan oleh Chaudhry ( 2012 ). Akan tetapi penelitian ini mendukung penelitian yang dilakukan Nurfitri (2009)

Hipotesis kelima (H5) yang menyatakan Kepemimpinan transformasional berpengaruh positif dan signifikan terhadap komitmen organisasional dapat diterima. Hal ini dibuktikan hasil analisis yang menunjukkan terdapat pengaruh positif dan signifikan dengan koefisien $(0,297)$ dan $p$-value $(0,000)$, yang artinya bahwa kepemimpinan transformasional yang meningkat akan secara signifikan meningkatkan komitmen organisasional. Pada variabel komitmen organisasional indikator komitmen kontinyu dengan item keinginan untuk terus bekerja dan menjadi bagian organisasi diberi penilaian paling tinggi oleh responden dengan skor 4.32. Artinya pada rumah sakit Muhammadiyah Ahmad Dahlan Kediri Pemimpin transformasional mampu menggerakkan bawahannya melebihi poses dasar pertukaran ekonomis. Penelitian ini mendukung teori dari Bass, (1985), Noel M,Tichy dan David Urich (1984) dan mendukung penelitian yang dilakukan oleh Griffith ( 2013 ) dan penelitian Prasetyo (2008) Hipotesis keenam (H6) yang menyatakan Kepemimpinan transaksional berpengaruh positif dan signifikan terhadap komitmen organisasional tidak dapat diterima. Hal ini dibuktikan hasil analisis yang menunjukkan terdapat pengaruh positif dan tidak signifikan $(\beta=-0.032, p=0.828)$, yang artinya bahwa kepemimpinan transaksional yang meningkat tidak akan meningkatkan komitmen organisasional. Faktor yang 
membuat kepemimpinan transaksional berpengaruh tidak signifikan terhadap komitmen organisasional adalah pada variabel kepemimpinan transaksional pada indikator contingent reward. Dimana pada rumah sakit Muhammadiyah Ahmad Dahlan Kediri pemberian imbalan yang sesuai dengan pekerjaan yang dilakukan karyawan mendapat nilai paling rendah dari responden, yang menjadikan kepemimpinan transaksional berpengaruh tidak signifikan terhadap komitmen organisasional karena pegawai masih belum merasa puas dengan imbalan yang diberikan dan berakibat rendahnya komitmen organisasionalnya. Faktor lain adalah sebagian karyawan merasa tidak memiliki keterikatan emosional yang tinggi terhadap rumah sakit hal ini bisa saja mengakibatkan turn over karena pegawai menganggap rumah sakit tempatnya bekerja bukanlah salah satu organisasi yang pantas untuk dipertahankan. Penelitian ini tidak mendukung pendapat dari Bass dan Avolio (1993) dan tidak mendukung penelitian yang dilakukan oleh Prasetyo (2008)

Hipotesis ke tujuh (H7) yang menyatakan budaya organisasi berpengaruh terhadap motivasi kerja dapat diterima. Hal ini ditunjukkan dari hasil analisis bahwa terdapat pengaruh positif dan signifikan $(\beta=0.489, \mathrm{p}=$ 0.000 ), yang artinya bahwa budaya organisasi yang meningkat akan meningkatkan motivasi kerja. Faktor yang mendukung bahwa budaya organisasi mampu mempengaruhi motivasi kerja adalah, pada variabel budaya organisasi indikator tertinggi yang dipilih oleh reponden adalah pada indikator perhatian pada hal-hal yang rinci dimana item penyelesaian tugas yang dibebankan dilakukan sesuai dengan prosedur dengan skor 4.19. Budaya organisasi harus dirangsang untuk dapat memotivasi karyawan guna mencapai tujuan organisasi Lingkungan sosial tempat kerja yang kondusif ternyata sangat mempengaruhi semangat dan motivasi kerja karyawan dalam suatu organisasi. Apabila karyawan cocok dengan budaya organisasi didalam suatu perusahaan tersebut maka akan meningkatkan motivasi kerja karyawan. Hal ini sesuai dengan pendapat Simamora, (1995:327) dan mendukung pendapat dari Robbins (2001),yang didukung oleh penelitian yang dilakukan oleh Sokro (2012)

Hipotesis kedelapan (H8) yang menyatakan motivasi kerja terdapat pengaruh yang positif terhadap komitmen organisasional. Hasil analisis menunjukkan terdapat pengaruh positif dan signifikan $(\beta=0.773, p=0.000)$, yang artinya bahwa motivasi kerja yang meningkat akan secara signifikan meningkatkan komitmen organisasional. Faktor yang diduga memiliki peran bahwa motivasi kerja berpengaruh terhadap komitmen organisasional adalah indikator akan kekuasaan. Dimana setiap item dari indikator akan kekuasaan ini memiliki skor tinggi, yaitu untuk item setiap pegawai diberi kewenangan dan tanggung jawab pada pekerjaan yang ditugaskan dengan skor 4.24, untuk item kewenangan untuk menyampaikan gagasan yang mendukung tujuan organisasi memiliki skor 4.18 dan item untuk mendapatkan kedudukan yang lebih baik dengan persaingan yang sehat memiliki skor 4.21. Hal tersebut menunjukkan bahwa motivasi pegawai rumah sakit Muhammdiyah Ahmad Dahlan Kediri untuk bekerja karena memilki peluang untuk berprestasi dan adanya peluang yang luas untuk suatu jabatan yang sesuai dengan pekerjaan. Setiap pegawai memiliki peluang yang sama untuk bersaing. Faktor ini yang mengakibatkan adanya motivasi kerja yang tinggi yang akhirnya menumbuhkan semangat berkomitmen organisasional yang tinggi. Hasilpenelitian ini mendukung pendapat dari Lyons et al (1993) dan Flecther and Williams (1996) dan mendukung penelitian yang dilakukan oleh Puspasari (2012)

Hasil analisis menunjukkan terdapat pengaruh positif dan signifikan $(\beta=0.513, \mathrm{p}=$ 0.000 ), yang artinya bahwa komitmen organisasional yang meningkat akan secara signifikan meningkatkan kinerja karyawan. Diduga faktor yang mendukung variabel komitmen organisasional sehingga mempengaruhi kinerja karyawan yaitu pada indikator 2 dengan item keinginan terus bekerja dan menjadi bagian dari organisasi yang diberi 
skor tertinggi oleh responden 4.06. Artiya bahwa pegawai rumah sakit Muhammadiyah Ahmad Dahlan Kediri merasa nyaman untuk tetap bekerja pada organisasinya dengan harapan untuk tetap bisa menjadi bagian dari organisasi dan berupaya untuk terus bekerja sehingga berdampak pada meningkatnya kinerja karyawan. Suatu komitmen organisasional menunjukkan suatu daya dari seseorang dalam mengidentifikasi keterlibatannya dalam suatu bagian organisasi. Komitmen organisasi dibangun atas dasar kepercayaan karyawan atas nilai-nilai organisasi, kerelaan karyawan membantu mewujudkan tujuan organisasi dan loyalitas karyawan untuk tetap menjadi anggota organisasi. Hal ini sesuai dengan pendapat Meyer dan Allen (1990) Mowday, Porters \& Steers,(1981), Ward dan Davis (1995) dan didukung penelitian yang dilakukan Puspasari (2012).

Hipotesis kesepuluh (H10) yang menyatakan kepemimpinan transformasional terdapat pengaruh yang positif terhadap kinerja karyawan. Hasil analisis menunjukkan terdapat pengaruh positif dan tidak signifikan yang artinya bahwa kepemimpinan transformasional yang meningkat tidak akan meningkatkan kinerja karyawan. Pada variabel kepemimpinan transformasional terdapat 2 indikator yang memiliki skor rendah dari jawaban para responden. Kedua indikator tersebut adalah indikator inspirasional dengan item tindakan yang dilakukan pimpinan tidak sesuai dengan harapan. Indikator perhatian dengan item perhatian pimpinan akan kebutuhan bawahan dengan skor 3.56. Akibatnya berdampak pada tidak terpengaruhnya kinerja karyawan terutama pada indikator kemampuan pada item penempatan pegawai yang tidak sesuai dengan ketrampilan yang dimiliki. Hal ini yang pada akhirnya mendorong pegawai tidak termotivasi pada pekerjaan yang dibebankan kepadanya.Penelitian ini tidak mendukung teori dari Luthan (2006) dan tidak mendukung penelitian yang dilakukan Solechah dkk (2011) dan Rasyid (2013).

Hipotesis kesebelas (H11) yang menyatakan kepemimpinan transaksional terdapat pengaruh yang positif terhadap kinerja karyawan. Hasil analisis menunjukkan terdapat pengaruh positif dan signifikan $(\beta=0.248, \mathrm{p}=$ 0.040), yang artinya bahwa kepemimpinan transaksional yang meningkat akan secara signifikan meningkatkan kinerja karyawan. Diduga faktor yang kuat mempengaruhi pada variabel kepemimpinan transaksional adalah pada indikator 2 yaitu management by exception active terutama pada item pimpinan selalu memberikan standard-standard kerja yang harus dipatuhi setiap pegawai dengan skor yang diberikan oleh responden 4.18. Hal ini diduga berpengaruh pada kinerja karyawan terutama pada indikator kualitas pekerjaan pada item berpenampilan baik dan rapi di tempat kerja. Memberikan fasilitas kepada pengikut supaya lebih akrab dengan kewajiban pekerjaan serta memahami tujuan untuk bisa mencapai kinerja yang diharapkan merupakan aspek penting dari gaya kepemimpinan transaksional. Penelitian ini mendukung pendapat dari Avolio. Bass, \& Jung, (1999) dan mendukung penelitian yang dilakukan Hartanto (2014).

\section{Kesimpulan dan Rekomendasi \\ Kesimpulan}

1. Terdapat pengaruh yang signifikan antara kepemimpinan transformasional terhadap budaya organisasi. Kepemimpinan transformasional yang meningkat akan secara signifikan meningkatkan budaya organisasi. Pemimpin yang transformasional cenderung visioner dan antusias, dengan sifat mampu memotivasi bawahannya (Bycio dkk, 1995; Howell \& Avolio, 1993). pada kepemimpinan transformasional, ditemukan bahwa memiliki dampak positif terhadap budaya stabilitas pada rumah sakit Muhammadiyah Ahmad Dahlan Kediri. Dimana pimpinan memberikan faktor karisma, stimulasi intelektual, dan pertimbangan individu, merupakan instrumen yang paling banyak digunakan oleh para pemimpin transformasional untuk memberdayakan dan mengangkat bawahan mereka dan mengubahnya menjadi suatu bentuk kinerja yang lebih.Sehingga menimbulkan kondisi organisai dengan budaya stabilitas dengan berjalannya komunikasi antara pimpinan dan bawahan dengan baik. 
2. Terdapat pengaruh yang signifikan antara kepemimpinan transaksional dengan budaya organisasi. Para pemimpin transaksional cenderung untuk bekerja dengan cara membatasi budaya yang ada. Dalam hal kepemimpinan transaksional, ditemukan bahwa imbalan kontigensi memiliki dampak positif terhadap budaya keagresifan. Budaya keagresifan mengacu pada suatu bentuk keterikatan berdasarkan pada akumulasi biaya sehingga menghasilkan hubungan yang signifikan dengan imbalan kontigensi.

3. Terdapat pengaruh yang tidak signifikan antara kepemimpian transformasional dengan motivasi kerja. Hal ini dibuktikan dengan tidak terpengaruhnya kepemimpinan transformasional terhadap motivasi kerja. Dimana pegawai merasa tindakan pimpinan tidak sesuai dengan harapan yang menyebabkan tidak berpengaruh pada motivasi kerja para pegawai.

4. Terdapat pengaruh yang tidak signifikan antara kepemimpian transaksional dengan motivasi kerja. Kepemimpinan transaksional yang meningkat tidak akan meningkatkan motivasi kerja. Hal ini dikarenakan pegawai pada rumah sakit Muhammadiyah Ahmad Dahlan termotivasi kerja tidak didasarkan pada pertukaran ekonomis yang biasanya dilakukan oleh kepemimpinan transaksional. Pegawai melakukan tugasnya karena adanya pengakuan dari lingkunan sekitar atas profesinya dan hal itu menimbulkan motivasi kerja yang tinggi.

5. Terdapat pengaruh yang signifikan antara kepemimpinan transformasional terhadap komitmen organisasional. Semakin baik pelaksanaan gaya kepemimpinan transformasional akan semakin meningkatkan komitmen organisasional.

6. Terdapat pengaruh yang tidak signifikan antara kepemimpinan transaksional terhadap komitmen organisasional. Semakin baik penerapan kepemimpinan transaksional akan diikuti komitmen pegawai yang tinggi kepada organisasinya, namun hal ini tidak terjadi pada rumah sakit Muhammadiyah Ahmad Dahlan Kediri.

7. Terdapat pengaruh yang signifikan antara budaya organisasi terhadap motivasi kerja.
Semakin meningkat budaya organisasi akan semakin meningkatkan motivasi kerja

8. Terdapat pengaruh yang signifikan antara motivasi kerja terhadap komitmen organisasional. Motivasi kerja yang meningkat akan secara signifikan meningkatkan komitmen organisasional. Motivasi pegawai rumah sakit Muhammdiyah Ahmad Dahlan Kediri untuk bekerja adalah karena memilki peluang untuk berprestasi dan adanya peluang yang luas untuk suatu jabatan yang sesuai dengan pekerjaan.

9. Terdapat pengaruh yang signifikan antara komitmen organisasional terhadap kinerja karyawan. Komitmen organisasional yang meningkat akan meningkatkan kinerja karyawan.Bahwa pegawai rumah sakit Muhammadiyah Ahmad Dahlan Kediri merasa nyaman untuk tetap bekerja pada organisasinya dengan harapan untuk tetap bisa menjadi bagian dari organisasi dan berupaya untuk terus bekerja sehingga berdampak pada meningkatnya kinerja karyawan.

10.Terdapat pengaruh yang tidak signifikan antara kepemimpinan transformasional terhadap kinerja karyawan. Artinya kepemimpinan transformasional yang meningkat tidak akan meningkatkan kinerja karyawan.

11.Terdapat pengaruh yang signifikan antara kepemimpinan transaksional terhadap kinerja karyawan. Kepemimpinan transaksional yang meningkat akan meningkatkan kinerja karyawan.

\section{REKOMENDASI}

1. Untuk penelitian selanjutnya disarankan bersifat longitudinal ( penelitian jangka panjang ) sehingga mampu menggambarkan peritiwa dalam satu periode

2. Disarankan pada penelitian selanjutnya dapat meneliti lebih dari 1 jenis rumah sakit, agar penelitian dapat digeneralisasikan menjadi lebih luas. Misal dapat dilakukan penelitian pada rumah sakit pemerintah dan rumah sakit swasta sebagai pembanding.

3. Untuk penelitian mendatang sebaiknya menggunakan sampel dengan ukuran yang lebih besar. Penambahan jumlah sampel akan memberikan hasil yang 
berbeda pada hasil penelitian dan terdapat banyak kemungkinan temuan penelitian terbaru.

4. Disarankan untuk penelitian selanjutnya memungkinkan menyempurnakan dengan menggunakan variabel moderasi sehingga dapat menjelaskan konsep secara utuh. Selain itu dalam penelitian ini masih memungkinkan penambahan indikator dalam setiap variabelnya untuk lebih mewakili obyek yang digunakan

5. Disarankan kepada peneliti selanjutnya untuk melibatkan variabel-variabel yang belum diteliti

\section{DAFTAR PUSTAKA}

Asfar Halim (2009) Pengaruh Budaya Organisasi Terhadap Kinerja Pegawai (Studi Pada Dinas Informasi Komunikasi dan Pengolahan Data Elektronik Kota Medan )-Universitas Sumatera Utara Medan-Skripsi

Bass, Bernard M. (1985), "Leadership and Performance Beyond Expectation",: Free Press, New York
Gary Dessler, 1992, Manajemen Personalia,Teknik dan Konsep Modern, Diterjemahkan oleh Agus Dharma, Edisi Ketiga, Erlangga, Jakarta

Kusdi, 2011, Budaya Organisasi Teori, Penelitian dan Praktik- Salemba Empat Jakarta

Liu, W., D.P. Lepak, R. Takeuchi \& H.P. Sims (2003), "Matching leadership styles with employment modes: Strategic human resource management perspective, Human Resource Management Review, Vol. 13, pp. 127-152

Robbins, Stephen P, 2006, "Perilaku Organisasi, Edisi kesepuluh, PT Indeks. Jakarta

Simamora, Henry. 1997. Manajemen Sumber Daya Manusia. STIE YKPN. Yogyakarta. Sugiyono, 1999, Statistik Untuk Penelitian, Alfa, Jakarta

Singarimbun, asri, 1995, Metode penelitian dan Survey, LP3ES, Jakarta 